\title{
Transient fluid flow in the Binbei district of the Songliao Basin, China: Evidence from apatite fission track thermochronology
}

\author{
Xiang Caifu ${ }^{1,2 *}$, Martin Danišík ${ }^{3}$ and Feng Zihui ${ }^{4}$ \\ ${ }^{1}$ State Key Laboratory for Petroleum Resource and Prospecting, China University of Petroleum, Beijing 102249, China \\ ${ }^{2}$ College of Geosciences, China University of Petroleum, Beijing 102249, China \\ ${ }^{3}$ Department of Earth \& Oceanic Sciences, University of Waikato, Hamilton 3105, New Zealand \\ ${ }^{4}$ Prospecting and Exploration Institute of Daqing Oil Field, Heilongjiang 163458, China
}

(c) China University of Petroleum (Beijing) and Springer-Verlag Berlin Heidelberg 2013

\begin{abstract}
The Songliao Basin is famous for the Daqing Oilfield, the biggest in China. However, no economic hydrocarbon reservoir has been found in the northeastern Binbei district. Its thermal history, which is of great importance for hydrocarbon generation and migration, is studied with apatite fission track (AFT) thermochronology. Samples with depositional ages of the late Cretaceous ( $108-73 \mathrm{Ma})$ are analyzed. The AFT ages of the samples from reservoir rock (depositional age $>76.1 \mathrm{Ma}$ ) fall between the late Cretaceous $(72 \pm 5 \mathrm{Ma}$ ) and the early Eocene $(41 \pm 3 \mathrm{Ma})$ period, indicating their total annealing after deposition. In contrast, two samples from the main seals of the Qingshankou (depositional age $>89.3 \mathrm{Ma}$ ) and the Nenjiang Formation (depositional age > $73.0 \mathrm{Ma}$ ) are not annealed or partially annealed (AFT ages of $97 \pm 9 \mathrm{Ma}$ and $70 \pm 4 \mathrm{Ma}$, respectively). Because the maximum burial temperature $\left(<90{ }^{\circ} \mathrm{C}\right)$ evidenced by low vitrinite reflectance $\left(R_{0}<0.7\right)$ is not high enough to account for the AFT total annealing $\left(110-120^{\circ} \mathrm{C}\right)$, the transient thermal effect arising from the syntectonic fluid flow between the late Cretaceous and the early Eocene is proposed. Transient thermal effects from fluid flow explains the indicated temperature discrepancies between the AFT thermometer and the $R_{\mathrm{o}}$ thermometer because the transient thermal effect from the fluid flow with a temperature high enough $\left(110-120^{\circ} \mathrm{C}\right)$ to anneal the AFT thermometer does not last long enough $\left(10^{4}-10^{5}\right.$ yrs.) for an enhancement of the $R_{\mathrm{o}}$ (minimum $10^{6}$ $10^{7}$ yrs. under the same temperature). This indicates that dating thermal effect from fluid flow might be a new means to reconstruct the tectonic history. It also answers why the samples from the main seals are not annealed because the seals will prohibit fluid flow and supply good thermal insulation. The large-scale fluid flow in the Binbei district calls for a new idea to direct the hydrocarbon exploration.
\end{abstract}

Key words: Apatite fission track, vitrinite reflectance, transient fluid flow, Binbei district, Songliao Basin

\section{Introduction}

The thermal history of sedimentary basins reflects their tectonic evolution. It controls source rock maturation, hydrocarbon generation, migration and accumulation, and also influences the late-stage variation of trapped hydrocarbons (Lutz and Omar, 1991; Hansen et al, 2001). Apatite fission track (AFT) analysis is a method commonly used to trace sedimentary provenance and to quantitatively constrain the thermal history of sedimentary basins (Miller and Duddy, 1989; Resak et al, 2010; Danišík et al, 2010).

This study is intended to reconstruct the thermal history

*Corresponding author. email: xcf@cup.edu.cn

Received November 6, 2011 of the Binbei district of the Songliao Basin. There are several extraordinary features that make the thermal history an interesting area to study. The most obvious feature is from the hydrocarbon exploration. The Binbei district accounts for $1 / 3$ area of the whole Songliao Basin, but the hydrocarbon exploration here has failed to make any significant progress in the past fifty years (Yang et al, 1985; Wang et al, 2006b; Lin et al, 2009). The main source rocks of the Qingshankou and the Nenjiang formations have been discovered in more than 1,000 exploration wells and proved to be widely distributed in the whole district (Yang et al, 1985; Yang, 1985; Wang et al, 2006b; Lu et al, 2009) Their thermal evolution is the only question to be further specified. Limited research using vitrinite reflectance $\left(R_{\mathrm{o}}\right)$ and clay minerals indicate that the highest temperature $\left(75-93{ }^{\circ} \mathrm{C}\right)$ occurred at the late Cretaceous ( $\sim 65 \mathrm{Ma})$ and then cooled in the Cenozoic due to 
tectonic inversion and denudation ( $\mathrm{Cai}$ and $\mathrm{Fu}, 2005)$. The thermal gradient in the Cretaceous $\left(4.5-5.7^{\circ} \mathrm{C} / 100 \mathrm{~m}\right)$ was higher than that in the Cenozoic $\left(3.7-4.5^{\circ} \mathrm{C} / 100 \mathrm{~m}\right.$ ) (Ren et al, 2001; Cai and Fu, 2005; Su et al, 2006). However, the Binbei district should be further considered because most of the thermal data sets are from the north of the central depression zone (CDZ).

The Binbei district underwent tectonic uplifting and denudation during the inversion stage of the basin. But very few studies have discussed its specific tectonic evolutionary history mainly due to the shortage of sedimentary records $(\sim 500 \mathrm{~m})$, which makes it impossible to rebuild the long evolutionary history $(65-0 \mathrm{Ma})$ by traditional methods (Lu et al, 2000; Yu et al, 2005). Whether or not it has undergone the same tectonic evolutionary history as the southern part of the basin is a question to be further answered (Xiang et al, 2007). Due to the significance arising from both hydrocarbon exploration and tectonic evolution, three boreholes were targeted and sedimentary samples of late Cretaceous from the depth shallower than the present-day partial annealing zone (PAZ) were collected. The samples were analyzed by the AFT method and the results combined with available $R_{\mathrm{o}}$ data were used to quantify its thermal history and the controlling factors. The results allowed an identification of the thermal effect from fluid flow and provided new insights for hydrocarbon exploration and tectonic evolution.

\section{Geologic setting}

The Songliao Basin is one of the biggest lacustrine basins (an area of $26 \times 10^{4} \mathrm{~km}^{2}$ ) in the world. Exploration and development of the Daqing Oilfield in the central depression of the basin have played an important role in China's petroleum industry and in the advancement of non-marine petroleum geologic theories (Yang et al, 1985; Yang, 1985; Zhao et al, 2010). The Binbei district refers to the vast area of the Songliao Basin that lies to the north of the northwestward trending Binzhou fault along the railway from Harbin to Qiqihar (Fig. 1). It is characterized by tectonic units of the uplifting zones and/or slope zones surrounding the northern part of the CDZ ( $\mathrm{Lu}$ et al, 2000). Abundant hydrocarbons have been found in the south, but only limited hydrocarbons have been found in this district.

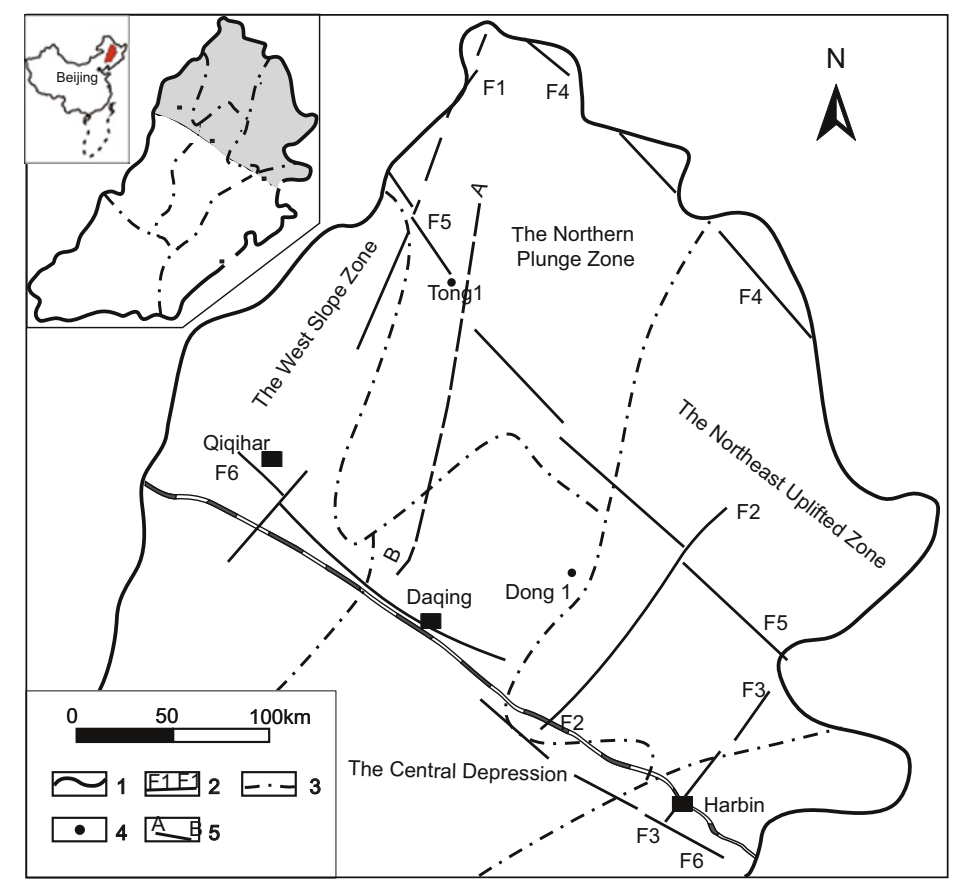

Fig. 1 Geological and tectonic characteristics of the Binbei district, Songliao Basin. 1: Boundary of the basin; 2: Fault; 3: Tectonic boundaries (See Yang et al (1985) for details); 4: Wells that have been sampled; 5: The profile shown in Fig. 2

The filling sequence of the district, which is identical with that of the Songliao Basin, can be classified into Jurassic rifting, early Cretaceous subsidence and late CretaceousCenozoic inversion (Yang et al, 1985; Feng et al, 2010a). The filling sequence and the tectonic feature can be best illustrated by a typical northeast profile from the central depression zone (CDZ) to the northern plunge zone (NPZ) (Fig. 2).

The synrift sequence (Jurassic-early Cretaceous) consists mostly of thick coal-bearing lacustrine and volcanic rocks that are controlled by syn-depositional faults (Fig. 2). It has been extensively studied due to the discovery of the big Qingshen gas reservoir (Feng, 2008; Zhao et al, 2008). The postrifting sequence (late Cretaceous) is made up of the upper Cretaceous Qingshankou, Yaojia and Nenjiang Formations, all of which are mainly lacustrine-fluvial mudstone, oil shale and sandstone according to both the numerous exploration wells and the China Cretaceous Continental Scientific Drilling Songke-I borehole (Wu et al, 2008; Cheng et al, 2009; Wang et al, 2009). The Qingshankou and the Nenjiang Formations provide the most important source rocks and seals in the basin. The Yaojia Formation provides the most prevailing reservoir rocks for the Daqing Oilfield (Yang et al, 


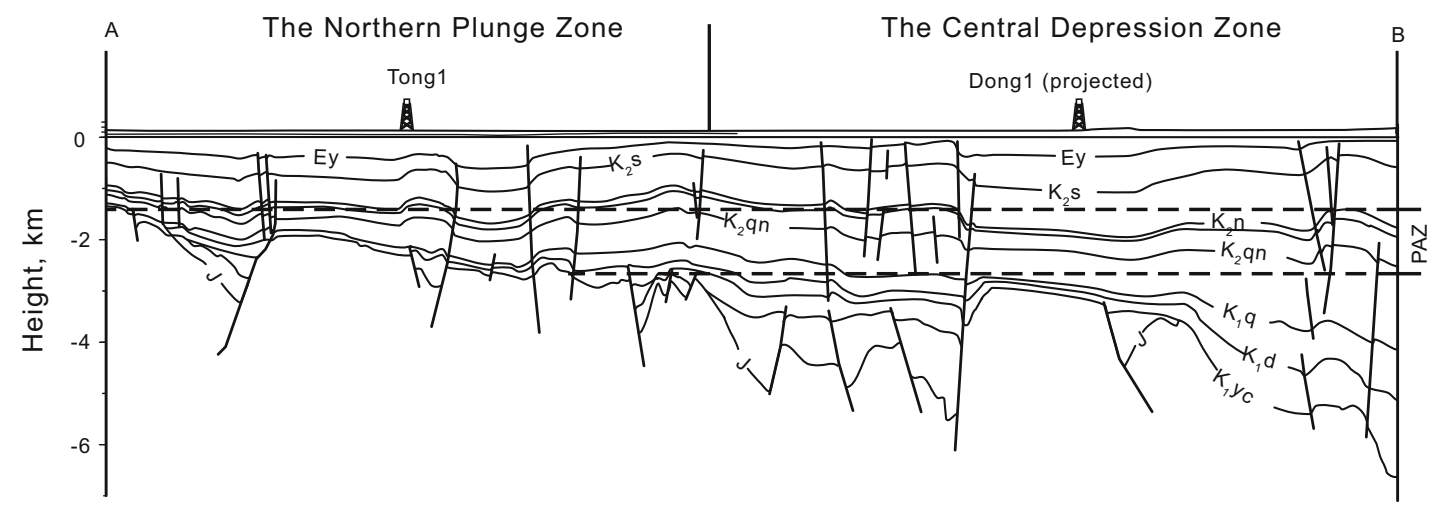

Fig. 2 Representative NE-trending cross-section from the CDZ to the NPZ illustrating the filling sequence and the tectonic framework. The post-Cretaceous sedimentary record is thin $(<500 \mathrm{~m})$ which makes it hard to reconstruct the tectonic evolutionary history by traditional methods

1985; Hou et al, 2004; Feng et al, 2010a).

The tectonic inversion sequence (late CretaceousCenozoic) is characterized by the moderate-total inversion and denudation of the NPZ and the northeast uplifted zone (NUZ) and by the subsidence and deposition in the west slope zone (WSZ) and the CDZ (Fig. 2 and Fig. 3). It is related to the westward compression from the east, which led to a quick shrinkage of the lacustrine basin and a westward migration of the subsidence and depositional centers (Yang et al, 1985; Feng et al, 2010a). The widely distributed inversion structures, including the Daqing anticline, were formed at this period (Song, 1997; Xiang et al, 2010). Structures in the NUZ and the CDZ are totally or moderately inverted, while those in the WSZ are only mildly inverted (Song, 1997).

\section{Sampling and methods}

Sampling targets were selected according to their tectonic features with the intention to reveal the tectonic and thermal evolution. The wells were selected on the basis of the extent of core segment availability in order to maximize the vertical sample distribution. As a result, ten sandstone samples were collected from three different wells, two of which are from the NPZ that is obviously influenced by tectonic uplifting and denudation. The samples cover the filling sequence from the Nenjiang Formation to the Denglouku Formation with the depositional ages ranging from $73 \mathrm{Ma}$ to $94.3 \mathrm{Ma}$ according to biostratigraphic and paleomagnetic study (Feng et al, 2010a; Wu et al, 2008) (Table 1).

The well temperatures that were determined during oil testing were used to constrain the burial temperature. According to the result (Fig. 4), the geothermal gradient is $\sim 4.5^{\circ} \mathrm{C} / 100 \mathrm{~m}$. Meteorological data from 101 observation stations over fifty years (1958 to 2007) show that the present mean annual land surface temperature in the basin ranges from -5 to $10{ }^{\circ} \mathrm{C}$ (Sun et al, 2009; Ma et al, 2009). Thus the surface temperature is assumed to be $10{ }^{\circ} \mathrm{C}$ (Zhou and Littke, 1999). The partial annealing zone (PAZ from Wagner et al, 1989) for the AFT thermometer is $60-120^{\circ} \mathrm{C}$, depending on mineral chemistry and cooling rate (Laslett et al, 1987; Ketcham et al, 1999), which corresponds to a burial depth of 1,300-2,700 m (Fig. 4). The samples cover a depth range from $\sim 200 \mathrm{~m}$ to $\sim 1,100 \mathrm{~m}$, which falls above the upper boundary of the PAZ and fits for the reconstruction of the thermal history (Table 1, Fig. 4).

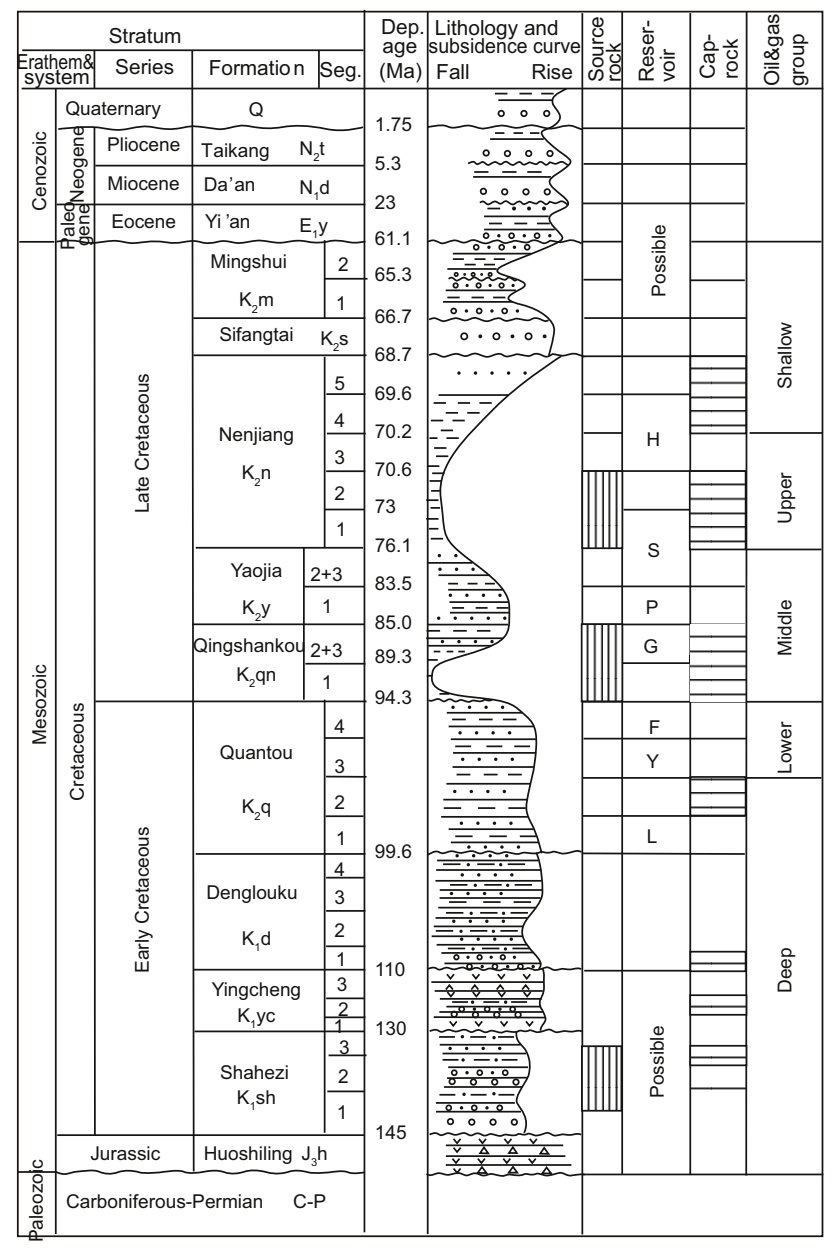

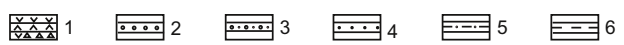

Fig. 3 Stratigraphic column and elements of the petroleum system in the Songliao Basin. 1: Volcanoclastic rocks; 2: Conglomerate; 3: Sandy conglomerate; 4: Sandstone; 5: Sandy shale; 6: Shale; Dep. Age: the minimum depositional ages according to Wu et al (2008) and Feng et al (2010a). Different reservoirs of Heidimiao (H), Saertu (S), Putaohua (P), Gaotaizi $(\mathrm{G})$, Fuyu $(\mathrm{F})$, Yangdachengzi $(\mathrm{Y})$ were developed and were best described in Feng et al (2010a) 
Table 1 Results of apatite fission track data from the Songliao Basin

\begin{tabular}{|c|c|c|c|c|c|c|c|c|c|c|c|}
\hline $\begin{array}{c}\text { Sample } \\
\text { No. }\end{array}$ & Well & $\begin{array}{c}\text { Burial depth, } \\
\text { m }\end{array}$ & $\begin{array}{c}\text { Form. } \\
\text { (Age_F) }\end{array}$ & $n$ & $\begin{array}{c}\rho_{\mathrm{s}}, 10^{5} / \mathrm{cm}^{3} \\
\left(N_{\mathrm{s}}\right)\end{array}$ & $\begin{array}{c}\rho_{\mathrm{i}}, 10^{5} / \mathrm{cm}^{3} \\
\left(N_{\mathrm{i}}\right)\end{array}$ & $\begin{array}{c}\rho_{\mathrm{d}}, 10^{5} / \mathrm{cm}^{3} \\
\left(N_{\mathrm{d}}\right)\end{array}$ & $\begin{array}{c}P\left(\chi^{2}\right) \\
\%\end{array}$ & $\begin{array}{c}\text { Central age } \\
\text { Ma } \\
( \pm 1 \sigma)\end{array}$ & $\begin{array}{c}\text { Pooled } \\
\text { age, Ma } \\
( \pm 1 \sigma)\end{array}$ & $\begin{array}{c}\text { MTL } \\
\mu \mathrm{m} \pm \mathrm{SD}(\mathrm{NL})\end{array}$ \\
\hline SBA1 & Dong1 & 716 & $\mathrm{~K}_{1} \mathrm{y}^{2+3}(76.1)$ & 28 & $2.395(504)$ & $1.896(399)$ & $2.156(3144)$ & 83.3 & $52 \pm 4$ & $52 \pm 4$ & $12.0 \pm 2.0(96)$ \\
\hline SBA2 & Dong1 & 763 & $\mathrm{~K}_{1} \mathrm{y}^{1}(83.5)$ & 28 & $2.854(484)$ & $2.388(405)$ & $1.797(3144)$ & 87.2 & $41 \pm 3$ & $41 \pm 3$ & $11.2 \pm 2.1(95)$ \\
\hline SBA3 & Dong1 & 942 & $\mathrm{~K}_{2} \mathrm{qn}^{1}(89.3)$ & 28 & $4.311(831)$ & $1.816(350)$ & $2.219(3144)$ & 10.9 & $97 \pm 9$ & $101 \pm 7$ & $11.5 \pm 1.7(99)$ \\
\hline SBA4 & Dong1 & 995 & $\mathrm{~K}_{1} \mathrm{q}^{4}(94.3)$ & 28 & $4.290(919)$ & $2.488(533)$ & $1.797(3144)$ & 99.1 & $59 \pm 4$ & $59 \pm 4$ & $11.7 \pm 1.8(99)$ \\
\hline SBA5 & Bai3 & 262 & $\mathrm{~K}_{1} \mathrm{n}^{1}(73)$ & 28 & 3.942 (1169) & $2.030(602)$ & $1.881(3144)$ & 99.3 & $70 \pm 4$ & $70 \pm 4$ & $12.1 \pm 1.6(105)$ \\
\hline SBA6 & Bai3 & 482 & $\mathrm{~K}_{1} \mathrm{y}^{2+3}(76.1)$ & 28 & $3.114(1010)$ & $2.109(684)$ & $1.797(3144)$ & 99.1 & $51 \pm 3$ & $51 \pm 3$ & $12.2 \pm 1.9(102)$ \\
\hline SBA7 & Bai3 & 760 & $K_{1} q^{4}(94.3)$ & 28 & $2.968(1161)$ & $1.853(725)$ & $2.113(3144)$ & 88.9 & $65 \pm 4$ & $65 \pm 4$ & $11.7 \pm 1.9(97)$ \\
\hline SBA8 & Bai3 & 770 & $\mathrm{~K}_{1} \mathrm{q}^{4}(94.3)$ & 28 & $3.904(855)$ & $1.909(418)$ & $1.649(3144)$ & 52.9 & $63 \pm 5$ & $65 \pm 5$ & $11.8 \pm 2.1(63)$ \\
\hline SBA9 & tong1 & 1069 & $\mathrm{~K}_{2} \mathrm{qn}^{2+3}(85.0)$ & 26 & $2.289(868)$ & $1.456(552)$ & $1.945(3144)$ & 44.1 & $56 \pm 4$ & $59 \pm 4$ & $11.4 \pm 1.8(84)$ \\
\hline SBA10 & tong1 & 1094 & $\mathrm{~K}_{2} \mathrm{qn}^{2+3}(85.0)$ & 28 & $2.496(1124)$ & $1.219(549)$ & $1.839(3144)$ & 23.8 & $72 \pm 5$ & $72 \pm 5$ & $11.7 \pm 2.0(100)$ \\
\hline
\end{tabular}

Notes: Burial depth: the depth below the surface; Form.: denotes the formation sampled; Age_F is the youngest age of the formation according to Wu et al (2008) and Feng et al (2010a); $n$ : the number of counted grains; $\rho_{\mathrm{s}} / \rho_{\mathrm{i}}$ : spontaneous/induced track densities respectively $\left(10^{5}\right.$ tracks/cm $\left.{ }^{2}\right) ; N_{\mathrm{s}} /$ $N_{\mathrm{i}}$ : number of counted spontaneous/induced tracks; $\rho_{\mathrm{d}}$ : dosimeter track density $\left(10^{5}\right.$ tracks $\left./ \mathrm{cm}^{2}\right) ; N_{\mathrm{d}}:$ number of tracks counted in dosimeter; $P\left(\chi^{2}\right)$ : probability obtaining chi-square value $\left(\chi^{2}\right)$ for $n$ degree of freedom (where $n$ is the number of crystals minus 1 ); the central ages are given for the sediment samples with high $P\left(\chi^{2}\right)$, where the $\pm 1 \sigma$ stands for the \pm 1 standard error (Galbraith and Laslett, 1993); MTL: mean horizontal confined track length; SD: standard deviation of track length distribution; NL: the number of horizontal confined tracks measured. The ages were calculated using the zeta calibration method (Hurford and Green, 1983), glass dosimeter CN-5 and a zeta value of $385 \pm 12$ yr./cm ${ }^{2}$. The well distribution can be found in Fig. 1

The samples were analyzed following the procedure outlined by Donelick et al (2005). After their separation using standard magnetic and heavy-liquid techniques, apatite grains were mounted in epoxy resin and polished to expose internal sections. The external detector method (Gleadow, 1981) was applied with the etching protocols of Carlson et al (1999) for apatite $\left(5.5 \mathrm{~mol} \mathrm{HNO}_{3}\right.$ for 20 seconds at $21{ }^{\circ} \mathrm{C}$ ). Low-uranium muscovite external detectors were packed together with sampled grain mounts and with Corning CN5 glass dosimeters and irradiated in the 492 swimmingpool hot-neutron nuclear reactor at the China Institute of Atomic Energy, Beijing. This reactor has a well-thermalized neutron flux with a $\mathrm{Cd}$ ratio for $\mathrm{Au}>100$. After irradiation, the muscovite external detectors were detached and etched in $40 \% \mathrm{HF}$ for 20 minutes at $25{ }^{\circ} \mathrm{C}$ to reveal the induced fission tracks. The ages were calculated using the Zeta calibration method (Hurford and Green, 1983; Hurford, 1990) with a Zeta value of $385 \pm 12$ year $/ \mathrm{cm}^{2}$. In order to increase the number of observable horizontal confined tracks, the samples were exposed to ${ }^{252} \mathrm{Cf}$ fission fragments (Donelick and Miller, 1991). Horizontal confined fission track lengths (e.g. Laslett et al, 1987; Gleadow et al, 1986) were measured only in prismatic apatite crystal faces because of the anisotropy of fission track annealing in apatite (Green et al, 1985). Where possible, up to 100 horizontal confined tracks were measured in the prismatic grains of each sample.

\section{Results}

Apatite fission track ages and lengths for 12 samples are given in Table 1. Both the radial plots and the histograms of the single grain ages (SGAs) are illustrated in Fig. 5. All the

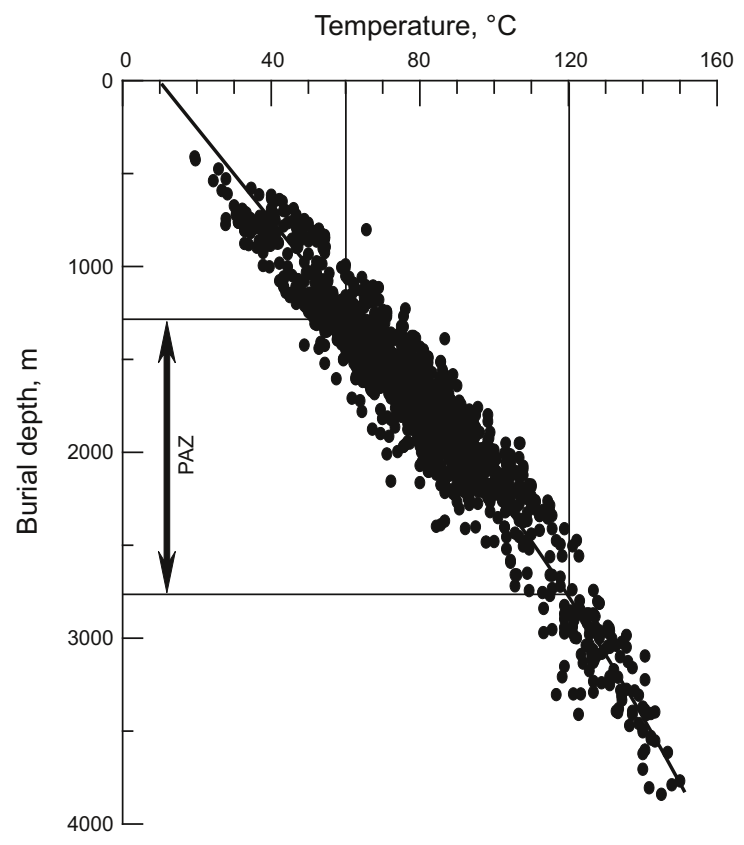

Fig. 4 Temperatures from drill stem tests (DST) and location of the present apatite PAZ

SGAs belong to the same age group indicated by passing the $\chi^{2}$-test and thus the pooled age is reported (Tagami and O'Sullivan, 2005).

\subsection{Lateral distribution}

The samples from well Dong1 represent all those from the northern part of the CDZ. The samples from the reservoir 
rocks fall in the Cenozoic period with ages ranging from $59 \pm 4$ Ma to $41 \pm 3$ Ma that are much younger than their Cretaceous depositional ages (Fig. 5), indicating total annealing. However, one sample from the Qingshankou Formation has AFT age of $101 \pm 7$ Ma that is older than its oldest depositional age of $94.3 \mathrm{Ma}$, indicating no annealing.

Samples SBA5 to SBA10 are from the NPZ. The oldest age $(72 \pm 5 \mathrm{Ma})$ was reported by sample SBA10 $(1,094 \mathrm{~m})$

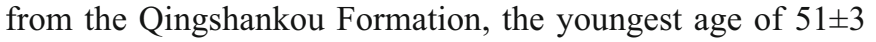
Ma was from sample SBA6 from the Yaojia Formation. All the AFT ages are younger than their youngest depositional ages of 73-94 Ma, which suggests total annealing.

Samples from wells Bai3 and Tong1 have successive burial depths ranging from $\sim 200 \mathrm{~m}$ to $\sim 1,100 \mathrm{~m}$. Their vertical distribution increased from $51 \pm 3 \mathrm{Ma}$ to $72 \pm 5 \mathrm{Ma}$ with an increasing burial depth from $\sim 500 \mathrm{~m}$ to $\sim 1,100 \mathrm{~m}$ if sample SBA5 is not considered. Sample SBA5 is from the Nenjiang Formation and is totally annealed, but more SGAs older than its depositional age are recorded.

All the samples are characterized by a unimodal track length distribution that is skewed to the left, which may indicate a simple thermal cooling according to the geologic settings (Fig. 5(c)).

\subsection{Vertical distribution}

The two seals of the Qingshankou and the Nenjiang Formations are good insulators for vertical heat transfer, which justifies our looking into the vertical age distributions of the samples that lie in the middle segment (between the Qingshankou and the Nenjiang Formations) and of the samples that lie in the lower segment (below the Qingshankou Formation) respectively (Fig. 6).

Samples with shallower burial depth show older ages in the lower segment. Samples from the middle segment show different characteristics. Younger ages were found in those samples that have shallower burial depth. It is contrary to our common expectation that the AFT age should become younger with the increasing burial depth (Wagner, 1981). If the AFT ages from the Qingshankou and the Nenjiang Formations are taken into consideration, the overall age distribution assumes a "bow" shape, with the youngest age found in the middle, and the age becomes older toward the main seals on both sides. The single grain age distribution has also shown the same characteristics. Samples from the main reservoir of the Yaojia Formation have younger and narrower SGA distribution, while those from the second and third segments of the Qingshankou Formation have more SGA (a)

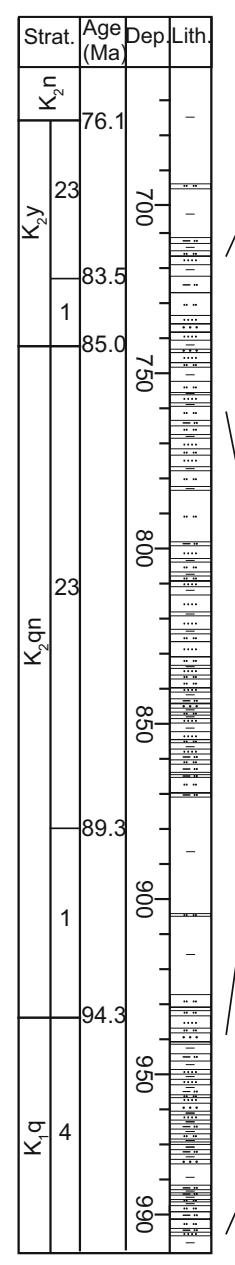

(b)
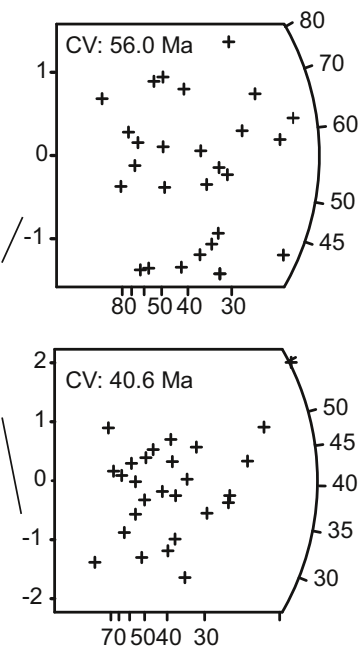

70504030
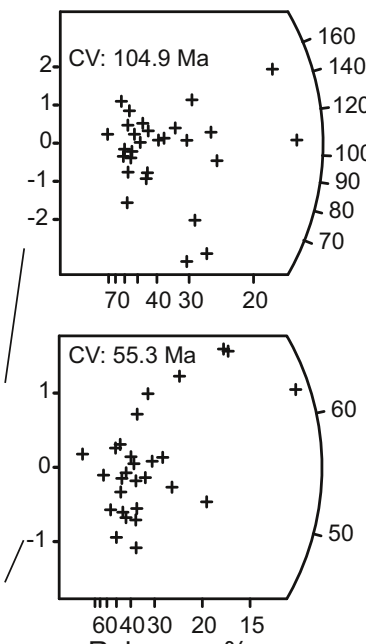

Rel. error, \% (c)
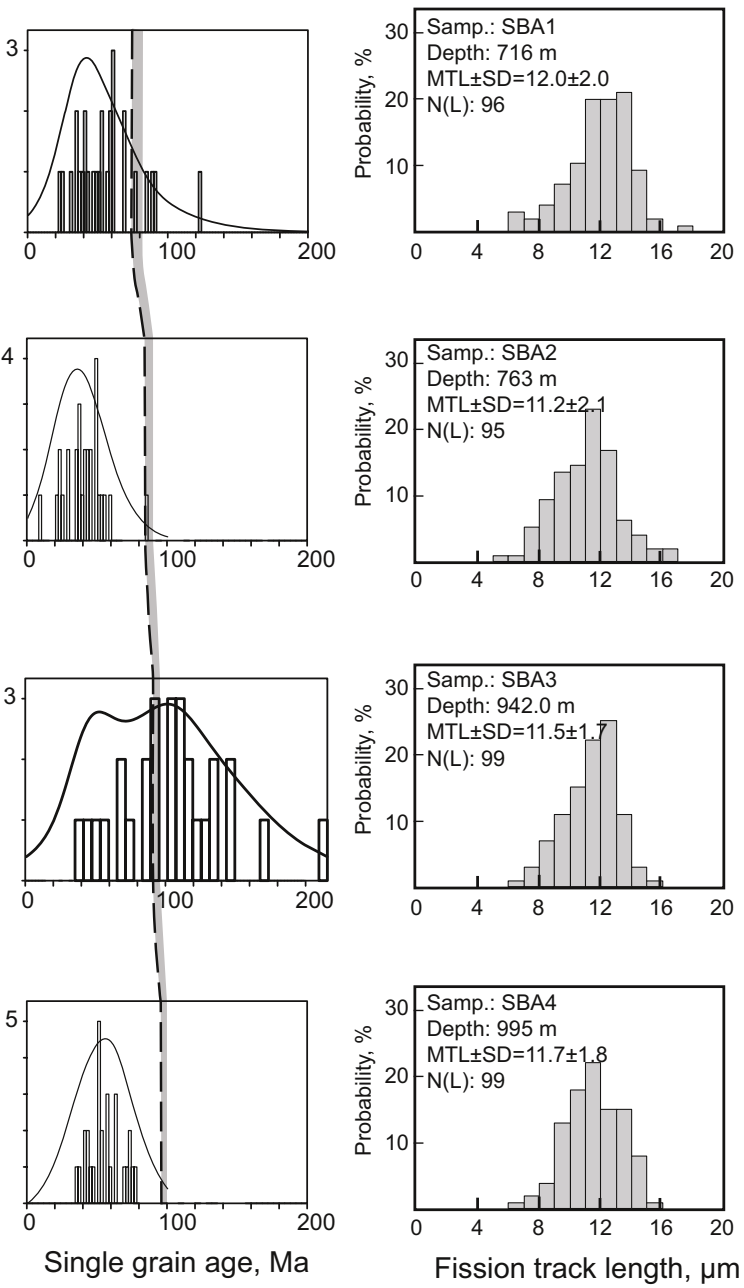
(a)
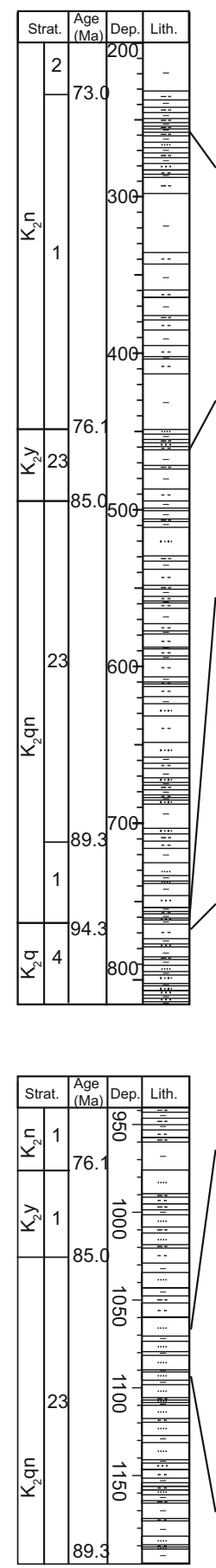

(b)
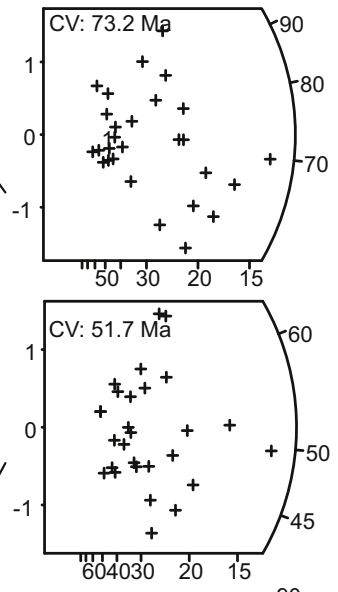

V: $69.4 \mathrm{Ma}+{ }^{90}$
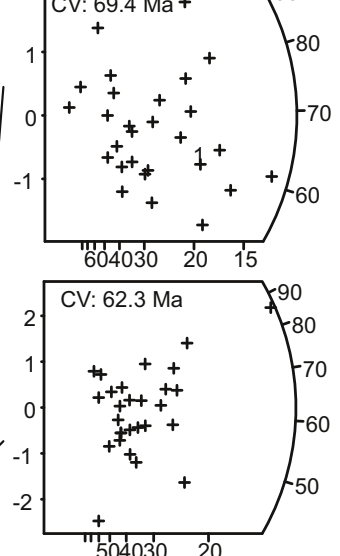

(c)
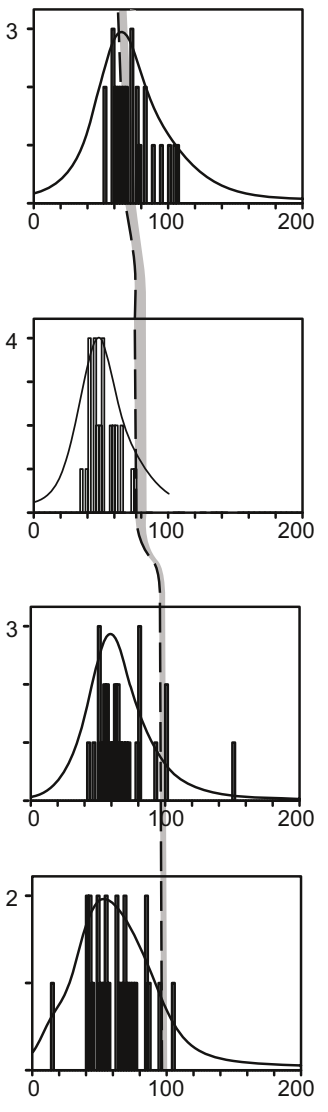

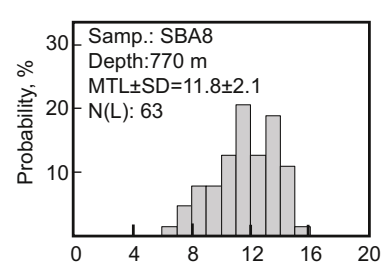

(d)
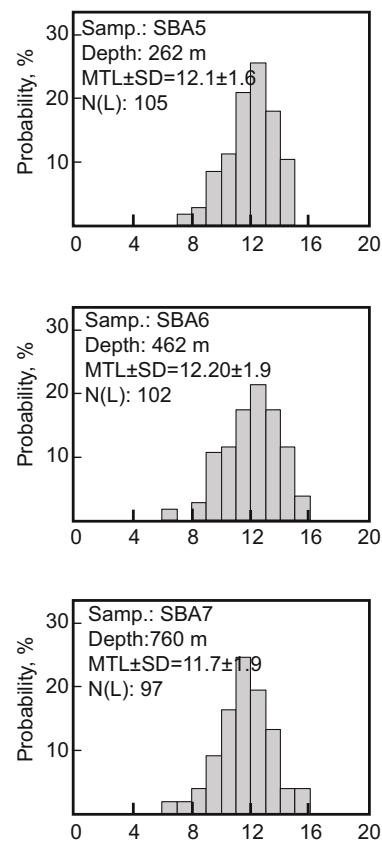

(Continued)
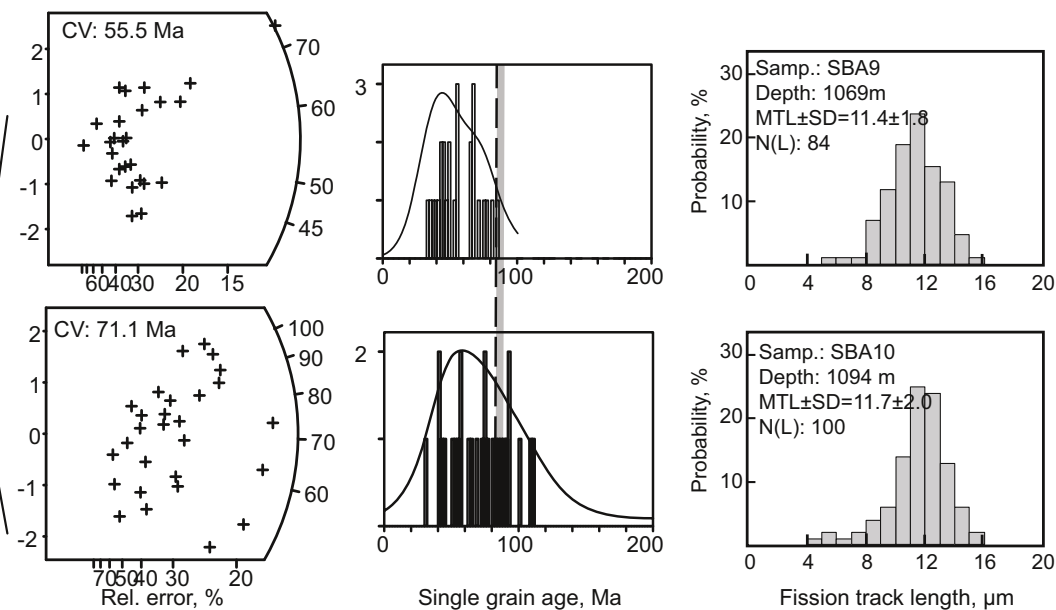

Fig. 5 AFT data displayed in radial plots after Galbraith (1990) (b) and histograms (c); AFT track length distribution (d) in the different tectonic belts in the Binbei district. Radial age plots left $y$-axis: $\delta$ error, $x$-axis: relative error in \%, right $y$-axis: age in Ma. The band across all the histograms denotes the minimum depositional ages of the samples

older than the depositional ages and wider SGA distributions.

The track length is becoming shorter vertically with the increasing burial depth. However, the track length is much shorter $(\sim 12 \mu \mathrm{m})$ than expected from the samples that are situated above the PAZ. The reason will be further discussed.

\section{Interpretation and discussion}

All AFT ages from samples of the main reservoir fall between the late Cretaceous (oldest AFT central age of $72 \pm 5$ $\mathrm{Ma})$ and the Eocene (youngest AFT central age of $41 \pm 3 \mathrm{Ma}$ ) period that are younger than their depositional ages and thus indicate that the samples have been heated up to the total annealing zone $\left(110-120^{\circ} \mathrm{C}\right)$ (Laslett et al, 1987; Wagner et al, 1989; Ketcham et al, 1999) (Fig. 5-Fig. 7). Two samples from the main seals of the Qingshankou and Nenjiang Formations have the AFT ages of $101 \pm 7 \mathrm{Ma}$ and $70 \pm 4 \mathrm{Ma}$ respectively. The former is older than its depositional age ( 89.3 


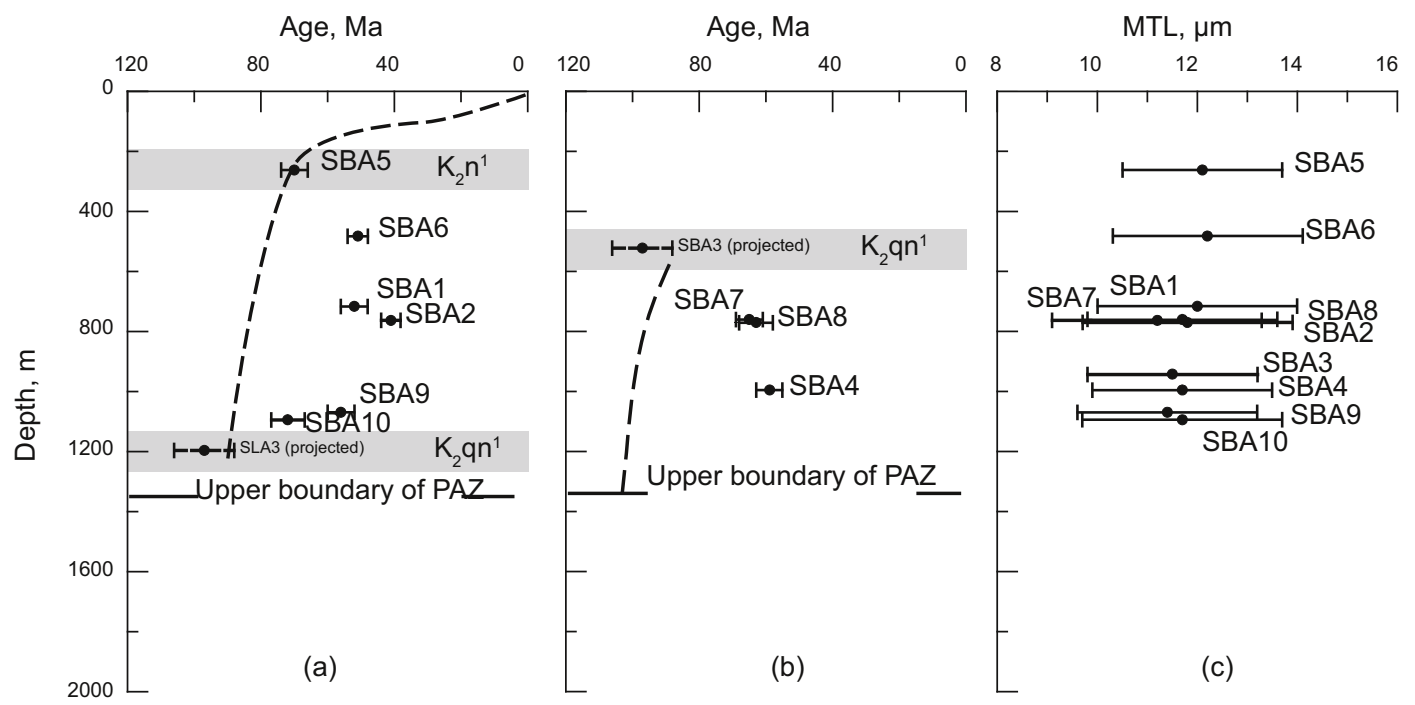

Fig. 6 Vertical variation of AFT ages (a and b) and AFT MTL (c) in the Binbei district. a-b: The central AFT age with $\pm 1 \mathrm{~s}$ standard error in the middle and the lower segments respectively. c: The MTL with standard deviation (Table 1). The presentday burial depth $(\mathrm{m})$ is shown on the left hand axis. The minimum depositional ages of the formation is shown by the dashed line. The main seals of the Qingshankou and the Nenjiang Formations are indicated by shadow rectangles that have been labeled by $\mathrm{k}_{2} \mathrm{qn}^{1}$ and $\mathrm{k}_{2} \mathrm{n}^{1}$ respectively.

Ma) without being annealed, whereas the latter is younger than its depositional age (73 Ma). The factors that lead to the different annealing characteristics between the reservoir rock and the seals and their geologic significances are discussed below.

\subsection{Burial heating}

Burial heating (due to either increased thermal gradients or burial depth), magmatism, and fluid flow are the most three common reasons that account for the resetting of AFT and zircon fission track (ZFT) thermometer (Ehlers, 2005). The annealing processes of all samples happened during the depression-inversion stage, during which there was no magmatism as indicated by precise Ar-Ar dating results of the volcanic rocks in northeast Asia (Wang et al, 2006a). We first take a close look at the burial processes with evidence from $R_{0}$, which was collected by the standard analytic procedure (ISO, 1994; ICCP, 1998). Only those data having a minimum number 20-30 particles, which are the minimum ones proposed for good estimation of the mean random $R_{\mathrm{o}}$ of dispersed organic matter (DOM) according to Barker and Pawlewicz (1993), were selected and their mean maximum $R_{\mathrm{o}}$ were used.

The vertical distribution of the mean maximum $R_{\mathrm{o}}$ from the NPZ and NUZ was shown in Fig. 7(a) and Fig. 7(b). $R_{\mathrm{o}}$ in the NPZ is more systematic, but $R_{\mathrm{o}}$ from the NUZ is more limited and sparser. Both of them increased vertically with the increasing burial depth. When the burial depth $<1,100$ $\mathrm{m}$, the deepest burial depth that has been sampled for our AFT dating, the $R_{\mathrm{o}}$ is $<0.7 \%$. Horizontal $R_{\mathrm{o}}$ distribution in the Quantou Formation, which is the lowermost formation that has been sampled, indicates that well Bai3 and well Tong1 are located in the NPZ, where $R_{\mathrm{o}}<0.5 \%$, while well Dong1 is located in the CDZ, where $R_{0}<0.7 \%$ (Fig. 7(c)).

To estimate the highest paleotemperature that has been indicated by the $R_{0}$, two factors that influence the maturation of the source rock should be considered. The first is the kerogen type. The source rocks in the Songliao Basin change from type I sapropelic kerogen in the CDZ to type III terrestrial kerogen at the margin due to changes in the depositional environments. As a result, the main kerogen types in the Binbei district are type II and type III kerogen (Yang et al, 1985). This excludes the higher paleotemperature needed for the same organic maturation that has been proposed for type I kerogen in the CDZ (Hutton and Cook, 1980). The second factor is the overpressure systems that might prohibit the metamorphism of the organic matters (Barker, 1989; Lo, 1993; Carr, 1999). There exist widely distributed abnormal high pressure systems in the $\mathrm{CDZ}$ of the Songliao Basin (Xiang et al, 2007). In this district, there are no abnormal pressure systems above the Quantou Formation because the upper boundary of the abnormal system is at the burial depth of $\sim 1,350 \mathrm{~m}$, which is deeper than most of the burial depths of the Quantou Formation (Xiang et al, 2007). Abnormal high pressure systems might have existed before the inversion of the Songliao Basin. If $R_{\mathrm{o}}$ from the Binbei district (type III kerogen with or without abnormal pressure systems) is compared with that from the CDZ (type I kerogen with obvious abnormal high pressure symstems), it should indicate a lower temperature than the same $R_{0}$ from the CDZ (Yang et al, 1985; Zhou and Littke, 1999).

According to the thermal evolution of the source rocks in the CDZ, the threshold of hydrocarbon generation is at a burial depth of $1,300 \mathrm{~m}$ and an $R_{\mathrm{o}}=0.5 \%$ that corresponds to a burial temperature $<60{ }^{\circ} \mathrm{C}$. When $0.5 \%<R_{\mathrm{o}}<1.0 \%$ (burial depth ranging between 1,300 $\mathrm{m}$ and 1,900 m), which corresponds to the maximum burial temperature of 60 $90{ }^{\circ} \mathrm{C}$, the source rocks were mature and began generating hydrocarbons (Yang, 1985; Zhou and Littke, 1999). The above defined thermal history has been proved by other independent parameters, such as spore colors, compositions of the kerogen $(\mathrm{H} / \mathrm{C}$ ratio and $\mathrm{O} / \mathrm{C}$ ratio), through thermal 


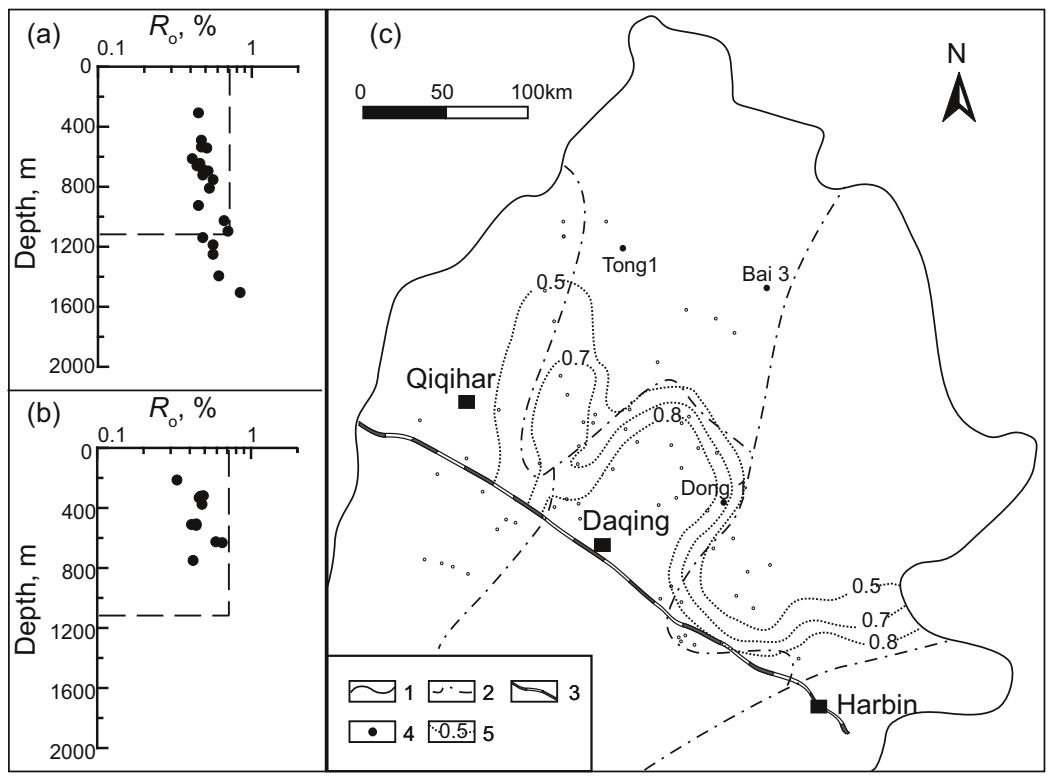

Fig. 7 Distribution of the vitrinite reflectance isolines from the Quantou Formation. a-b. Vertical distribution of the vitrinite reflectance from the NPZ and the NUZ respectively. c. Horizontal distribution of the vitrinite reflectance. The low $R_{\mathrm{o}}$ values of $<0.5 \%$ from well Tong 1 and well Bai3 and the $R_{\mathrm{o}}$ of $\sim 0.7 \%$ from well Dong1, which correspond to the highest burial temperature of $60-90{ }^{\circ} \mathrm{C}$, indicate that burial heating cannot account for the AFT total annealing

gravimetric analyses, and by the thermal evolution of saturated/aromatic hydrocarbons and clay minerals (I/S) (Yang et al, 1985).

Accordingly, the low $R_{\mathrm{o}}$ values of $<0.5 \%$ from well Tong 1 and well Bai3 indicate a burial temperature $<60{ }^{\circ} \mathrm{C}$ and the $R_{\mathrm{o}}$ of $\sim 0.7 \%$ from well Dong1 indicates a burial temperature of $60-90{ }^{\circ} \mathrm{C}$. Since the vitrinite reflectance tends to record the peak temperature (Baker and Goldstein, 1990), it is clear that the above defined burial temperature cannot lead to the total annealing of the AFT thermometer. We have to rely on some transient thermal effect to explain the AFT annealing and the temperature discrepancies between the AFT thermometer and the $R_{\mathrm{o}}$.

\section{2 Thermal annealing from fluid flow}

Thermal effects from different scales of fluid flow have a far greater influence on the temperature field than those from the lithosphere-scale events and have been widely documented (Blackwell and Steele, 1989; Ehlers, 2005). All the AFT ages from the samples that have been totally annealed range between the late Cretaceous and the early Eocene, during which time the Songliao Basin was under its tectonic inversion. Because almost all the tectonic movements involve the movement of fluid, our consideration of the thermal effect from fluid flow is justified (Sibson, 2000; 2003; Oliver and Bons, 2001; Stanislavsky and Garven, 2003; Barker et al, 2006). To seek foundations for our explanation, questions concerning the source, the driving mechanism and the pathway systems of the fluid should be first answered. The question "how the thermal effects from fluid flow control the AFT annealing" is then discussed.

\section{1) Source of the hot fluid}

High temperature fluids both from the CDZ and from the underlying rifting sequences existed. High temperature formation water and hydrocarbon fluid have been documented by fluid inclusions from the CDZ. The time of their existence and movement was between the late Cretaceous and the early Eocene. High temperature fluids must have existed at the underlying rifting sequence of the Binbei district as indicated by $>3 \mathrm{~km}$ burial depth (Fig. 2) and the high $\left(\sim 45^{\circ} \mathrm{C} / \mathrm{km}\right)$ geothermal gradient (Fig. 4).

\section{2) Driving mechanism}

Thermal effects from the fluid account for the AFT annealing, thus the AFT ages record the time of the fluid flow. Because all the samples that have been totally annealed record the time from the late Cretaceous (oldest age of $72 \pm 5$ $\mathrm{Ma})$ to the early Eocene $(41 \pm 3 \mathrm{Ma})$, during which time the basin underwent extensive inversion from east to west (Xiang et al, 2010), the fluid flow might have been syntectonic. It was triggered or driven by tectonic faulting or compression and was often advective fluid flow (Sibson, 2000; 2003; Oliver and Bons, 2001; Stanislavsky and Garven, 2003; Barker et al, 2006). There exist different mechanisms that could have driven the fluid flow to the Binbei district during the main stage of tectonic inversion.

One of the possible driving mechanisms is the fluid flow driven by the tectonic compression along the faults. Faults in the Binbei district are obvious as shown in Fig. 2. Some of them have cut through the main seals of the Qingshankou Formation. As the NW-strike faults tend to open during the main stage of the NW tectonic compression at the late Cretaceous (Sibson, 2000; 2003), it was easy for the hot fluid to migrate from the underlying formation vertically along the faults and enter the reservoir to reset the AFT thermometers.

Thermal effects from the hot fluid along the faults can be used for an easy explanation of the AFT annealing of the 
samples from well Tong 1 because it is situated on the vicinity of the NW faults. However, it is hard to account for those samples from the well Dong1 and well Bai3 because there are no obvious faults from the seismic cross section. The other mechanism of large-scale lateral fluid flow is proposed.

One of the driving mechanisms for large-scale lateral fluid flow is the combined effect from the abnormal high pressure systems that developed in the CDZ and from the tectonic compression, according to the model that has been well built (Sibson, 2000; 2003; Stanislavsky and Garven, 2003). The Qijia-Gulong Depression is characterized by an abnormal high fluid pressure (the pressure coefficient falls between 1.2 and 1.6), which is controlled by both the rapid burial processes and the hydrocarbon generation (Liu et al, 2000; Wang et al, 2002; Xiang et al, 2004). It is quite possible that the abnormal, highly pressurized fluid flow from the QijiaGulong Depression, triggered by the tectonic compression during the inversion of the Songliao Basin, will migrate to the NPZ and lead to the total AFT resetting.

Fluid flow driven by gravitational energy is the other possible contributor. It is best illustrated by Garven et al (1993) and its thermal effect has been recently reviewed by Bernet and Garver (2005). The difference of the elevation $(\sim 250 \mathrm{~m})$ between the east and the west has been recognized in the regional profile (Yang et al, 1985; Zhou and Littke, 1999; Xiang et al, 2007) if the main seal of the Qingshankou Formation or the Nenjiang Formation is taken as a reference. Such a difference might have been even greater at the end of the Eocene due to the elevation and denudation $(1,200-1,500$ m) (Xiang et al, 2010).

\section{3) Pathway systems}

Thermal effects from fluid flow indicate a lateral or vertical convective heat transfer, either of which is characterized by being more efficient than conductive heat transfer along the main pathway systems of the fluid flow (Ehlers, 2005). The pathway systems for the fluid in a basin have been defined as the permeable rock masses, which are the permeable sandstones and unconformities or the faults and fracture systems (Lin et al, 2009) (Fig. 1, Fig. 2).

Due to the lack of pathway systems for the hot fluid flow, the thermal effect may result in the sample's failure to be annealed. Sample SBA3 is from the main seals of the Qingshankou Formation that deposited during the main subsidence of the Songliao Basin. The fine grained sandstone in the seals is discrete and cannot form continuous pathway systems for the fluid from the CDZ. At the same time, the fine grained mudstone is characterized by low thermal conductivity, which will shield the vertical and lateral heat conductivity. The above two factors lead to the sample's failure to be annealed (Blackwell and Steele, 1989). The lateral connectivity of the permeable reservoir might account for the different characteristics of vertical AFT age distribution between the middle reservoirs group and the lower reservoirs group. The lower reservoirs group was deposited under a braided fluvial-shallow lake environment and is characterized by discrete fluvial channel sandstone bodies (Feng et al, 2010a), whereas the middle reservoirs group is controlled by the large fluvial-delta systems from the
Binbei district and the sandstone bodies are overlapped and well laterally connected (Feng et al, 2010b). The vertical AFT ages of those from the middle segment increased with the burial depth, indicating a local thermal effect from fluid flow (Tagami and O'Sullivan, 2005). Driven by the buoyancies that arose from their temperature differences, hot fluid from the CDZ tends to ascend to flow beneath the bottom of the main seals during its lateral migration. This resulted in younger ages with shallower burial depths (Fig. 6). Those samples from the lower segment are different as indicated by the younger ages with increasing burial depth. This may be either due to the limited sampling interval, which focuses on the upper part of the lower group, or indicates a limited temperature anomaly, which has no totally overturned thermal effect from conductivity due to the lack of lateral pathway connectivity.

\subsection{Transient fluid flow}

Thermal effects from the fluid flow accounts for the different annealing between the reservoir and the seals. The following discussion will be focused on the temperature discrepancy shown by the AFT thermometer and the $R_{\mathrm{o}}$ respectively.

\section{1) Transient thermal effect}

Research results indicate that the fluid flow of a regional scale, driven by topographic reliefs, may result in transient $\left(10^{4}-10^{5}\right.$ yrs. according to Ehlers, 2005) regional thermal anomaly as has been documented in the basin and province of the middle continent and the Paris Basin (Bachu, 1985; Garven et al, 1993). Local fluid flow in connection with the magmatism, tectonic faulting or seismic activity, and with the breakthrough of the abnormal high pressure systems, is instant and transient (Sibson, 2000; 2003; Stanislavsky and Garven, 2003). Both regional and localized thermal effects from fluid flow are transient and may account for the temperature discrepancy indicated by AFT thermometer and $R_{0}$ respectively.

Thermal effects from fluid flow are the only possible choice that can account for the AFT total annealing but will not result in a significant enhancement of $R_{0}$. Research results show that the maturation of the organic matters requires longer time than the resetting of the AFT. A minimum of $10^{6}$ $10^{7} \mathrm{yrs}$. of continuous heating (within $15^{\circ} \mathrm{C}$ of maximum temperature) is required to stabilize the thermal maturation of organic matters (Barker, 1989). Take the temperature range of $100-120{ }^{\circ} \mathrm{C}$ for example, decarbonxylation reactions with an Ea of $30-40 \mathrm{kcal} / \mathrm{mol}(130-170 \mathrm{~kJ} / \mathrm{mol})$, which is the activation energy for preferentially eliminating water and carbon dioxide during the early maturation stage (Burnham and Sweeney, 1989), require on the order of $10^{6}-10^{7} \mathrm{yrs}$. to approach completion (Barker, 1989). According to the evidences both from experiments and from the calculation based on the Arrhenius equation (Green et al, 1985), however, the time needed for AFT annealing $(<1$ year) at the same temperature $\left(100-120^{\circ} \mathrm{C}\right.$ ) is almost instant (Laslett et al, 1987; Green et al, 1985; Crowley et al, 1991).

The above time difference between the stabilization of the vitrinite reflectance and the total annealing of the AFT 
thermometer can help explain the temperature difference indicated by AFT total annealing $\left(110-120{ }^{\circ} \mathrm{C}\right)$ and the vitrinite reflectance $\left(60-90{ }^{\circ} \mathrm{C}\right.$ with $\left.R_{\mathrm{o}}<0.7 \%\right)$. The duration of the thermal effect from the fluid flow (which lasts typically on the order of $10^{4}-10^{5} \mathrm{yrs}$. according to Ehlers (2005)) is not long enough to affect the $R_{\mathrm{o}}$, although its temperature is high enough to reset the AFT thermometer.

\section{2) Episodes of fluid flow}

Transient fluid flow indicates that fluid flow happened at some point between the late Cretaceous and the early Eocene. It should be treated not as the time span over which the fluid flow has lasted, but typically as the time point when one or more episodes of fluid flow have been driven or triggered by tectonic compression. For a more accurate time table of the fluid flow, and consequently the time table for the tectonic activity, special attention should be paid to how the fluid and the pathway system cool down after the main episode of fluid flow.

The cooling velocity of the fluid flow depends on the temperature differences between the fluid flow and the wall rock. Higher temperature differences will result in a higher cooling velocity and more accurate time will be recorded by AFT age because the AFT ages record the time when the temperature passed the upper boundary of the PAZ (Gleadow et al, 1986). Regardless the cooling effect of the fluid during its migration along the pathway systems, the temperature difference between the fluid and wall rock then depends on the burial temperature which is closely linked to the burial depth. The post-rifting sequence is a depression with the burial depth increasing from the periphery to the basin center as shown in Fig. 2. Higher temperature differences between the fluid flow and the wall rock are found in samples from well Tong3 and well Bai3, both of which are located at the margin of the basin.

Limited samples from well Tong3 and well Bai3 indicate three episodes of fluid flow at late Nenjiang (72 $\pm 5-70 \pm 4$ $\mathrm{Ma})$, late Cretaceous (65 $\pm 4-63 \pm 5 \mathrm{Ma})$, and late Paleocene (56 $\pm 4-51 \pm 3 \mathrm{Ma}$ ) periods respectively (Table 1, Fig. 5). All of them fall in the standard deviation of the \pm 1 standard error of the AFT dating and their accuracy is acceptable (Galbraith and Laslett, 1993). Due to the transient characteristics of the thermal effect from fluid, they should not be treated as the same episode of fluid flow because the time lasts so long that the maturation of the organic matter will be enhanced. Although limited samples may fail to support the above conclusion, its reliability is supported by the geologic background of the Songliao Basin.

The thermal effect from syntectonic fluid flow suggests that there must have been some tectonic activity that can drive or trigger the fluid flow. According to the geologic setting, three episodes of tectonic movement in the Songliao Basin are well established. The first episode appeared before the deposition of the third member of the Nenjiang Formation, as indicated by the progradation effect of the filling sequence from the east (Feng et al, 2010a; 2010b). The second episode of tectonic movement happened at the late Cretaceous (65 $\mathrm{Ma}$ ), which marked the beginning of tectonic inversion with more than $750 \mathrm{~m}$ of erosion recorded by AFT dating from the south uplifted zone (Xiang et al, 2007). The third episode of tectonic activity occurred in the late Paleocene (56 Ma) and might have arisen from the combined effect of the subduction of the Pacific Plate underneath the Eurasian Plate (Patriat and Achache, 1984; Gordon and Jurdy, 1986; Maruyama et al, 1989; Lee and Lawver, 1995; Sharp and Clague, 2006) and of the collision between the Indian subcontinent and the Eurasian Plate (Maruyama and Send, 1986; Lee and Lawver, 1995). The third episode of tectonic movement in the Songliao Basin must have lasted till the early Eocene as suggested by the AFT dating from the south uplifted zone of the basin (Xiang et al, 2007).

It is hard to provide more evidence to prove the abovementioned three episodes of fluid flow. However, we can suppose all samples from well Dong1 as tests and get further information.

Three samples from well Dong1 that have been totally annealed record AFT age of $59 \pm 4 \mathrm{Ma}, 52 \pm 4 \mathrm{Ma}$ and $41 \pm 3 \mathrm{Ma}$ respectively. The first two ages fall within the late Paleocene. The limited data from well Dong1 have proved at least the last episode of fluid flow, but failed to prove the two episodes of fluid flow that happened at the late Nenjiang and late Cretaceous periods. At the same time, one sample records another age of the early Eocene ( $41 \pm 3 \mathrm{Ma})$. Whether they are reliable or not is worth discussion.

\subsection{Thermal overprinting}

Thermal effects from fluid flow left only their footprints on the pathway systems. This leads to the following two results. Syntectonic fluid flow tends to change its pathway systems (Oliver and Bons, 2001; Baker et al, 2006) that cause some of their thermal effects to fail to be recorded. Thus large-scale fluid flow will leave its thermal effect in a broad range and small-scale fluid flow will only leave its footprint on limited reservoir rocks. On the other hand, the unchanged pathway systems will only preserve the thermal effect of the latest episode of fluid flow due to its overlapping on the thermal effect of the early-stage thermal event. The above two characteristics can explain the AFT ages that record the thermal effect from fluid flow.

The second characteristic of the thermal effect from fluid flow gives us a direct clue to explain the AFT data from the well Dong1 which is nearer to the CDZ. The CDZ has a high pressurized fluid flow with a high temperature and can be easily triggered or driven by the tectonic movement. Thus, thermal effects from the late Paleocene fluid flow must have totally overlapped those from the late Nenjiang and the late Cretaceous periods and caused their lack of preservation as AFT ages.

The first characteristic of the fluid flow gives us more information as follows. First, real large-scale fluid flow will leave its footprint in a wide range of pathway systems, which in turn makes it easier to be sampled and recorded. The late Paleocene large-scale fluid flow can be ascertained because it has been recorded by samples from the three wells that are scattered in a vast area and vertically from $\sim 500-1,100 \mathrm{~m}$. The late Nenjiang fluid flow and late Cretaceous fluid flow should be more obvious than the early Eocene fluid flow 
because they were recorded by samples from well Bai3 and well Tong1, both of which are located in farther north than well Dong1. The early Eocene fluid flow is only recorded at good reservoirs of the first member of the Yaojia Formation near CDZ, which in turn indicates its limited thermal effect and distribution.

The above two assumptions may have wide applications in dating the tectonic movements if they have been further proved. Tectonic reconstruction relies heavily on the rock framework, the lack of which will cause big challenges. The late-stage tectonic movement in the Songliao Basin, starting from the late Cretaceous ( $\sim 65 \mathrm{Ma}$ ) with $<500 \mathrm{~m}$ sedimentary record, is one of such challenges. Our analysis defines at least three episodes of tectonic movement with the time much more accurately defined than anticipated. What is more, if tectonic movements can be dated by their syntectonic fluid flow, all the methods that date the fluid flow and the thermal events can be used to quantify the timetable of the tectonic movements. Thus, dating the time of the tectonic activity by dating the syntectonic fluid flow and its thermal effect should evolve into a new method. Thermal overprinting by the fluid flow may also account for the shortened AFT MTL distribution (Fig. 6). The MTL distribution may be attributed to the sluggish annealing kinetics for the sample's long time (30-65 Ma) of location in the low temperature range of $<70$ ${ }^{\circ} \mathrm{C}$ (Spiegel et al, 2007). According to the above discussion, transient thermal effects from fluid flow with the temperature between $60^{\circ} \mathrm{C}$ and $120^{\circ} \mathrm{C}$ can easily lead to partial annealing of the AFT, as indicated by the shortening of the MTL.

\subsection{Source rock maturation and hydrocarbon exploration}

Thermal history is the key factor that controls source rock maturation and the successive hydrocarbon migration and accumulation. There are two families of source rocks that developed in the Songliao Basin, namely the Qingshankou and the Nenjiang Formations (Yang, 1985; Lu et al, 2009; Feng et al, 2010a). The proposed thermal effects have important implications for hydrocarbon exploration in the Binbei district.

Hydrocarbon exploration under the guide of conventional hydrocarbon exploration around local pods of active source rocks in the Binbei district has never gained a prominent outcome. This is mainly due to the low matured source rocks that have been proved both by the low $R_{\mathrm{o}}$ (Fig. 7) and by the unannealed AFT age (Fig. 5) from the main source rock of the Qingshankou Formation.

The defined thermal effect from fluid flow, however, gives a new idea to overcome the above stalemate. Hydrocarbon exploration around the active source rocks should be changed to look for the hydrocarbons that have migrated from the main active source pods in the CDZ. The late Paleocene fluid flow is a large-scale fluid flow that has left its footprint both on the vicinity of the mature source region (samples from well Dong1) and in those areas farther north of the Binbei district, where $R_{\mathrm{o}}<0.5 \%$. The two sets of source rocks that have been buried up to the threshold of hydrocarbon generation (Yang et al, 1985) before the Paleocene justify our assumption of the large-scale hydrocarbon migration together with the migration of the formation fluid flow. Independent evidence from the composition and the geochemistry of the natural gas and the crude oils has demonstrated a long range hydrocarbon migration in the basin (Feng et al, 2003; Xiang et al, 2004; 2005).

\section{Conclusions}

AFT dating in the Binbei district further clarifies its thermal history and has important implications for hydrocarbon exploration. The following are the most significant results:

1) The AFT ages of samples from the Cretaceous reservoir rocks (youngest deposition age of $76.1 \mathrm{Ma}$ ) fall between the late Cretaceous (the oldest AFT age of $72 \pm 5 \mathrm{Ma}$ ) and the early Eocene (the youngest age of $41 \pm 3 \mathrm{Ma}$ ), indicating AFT thermometer total annealing after deposition. Two samples from the main seals of the Qingshankou (the youngest depositional age of $89.3 \mathrm{Ma}$ ) and Nenjiang (the youngest depositional age of 70.6 Ma) Formations yield AFT ages (70 \pm 4 Ma and $97 \pm 9$ Ma respectively) identical with or older than the depositional ages, indicating partial or no annealing.

2) Thermal effects from syntectonic fluid flow are proposed to account for the AFT total annealing because the burial heating is not high enough as evidenced by low $R_{\mathrm{o}}(<0.7 \%)$. Driven by the tectonic compression and the abnormal pressure systems, the fluid flow from the CDZ or from the underlying rifting sequences is proposed to account for the AFT total annealing.

3) The characteristics of the transient thermal effect from the syntectonic fluid flow help explain the indicated temperature discrepancies between the AFT thermometer and the $R_{0}$. Thermal effects from fluid flow are hot enough (110$120{ }^{\circ} \mathrm{C}$ ) to anneal the AFT thermometer, but they do not last long enough $\left(10^{4}-10^{5} \mathrm{yrs}\right.$.) to enhance $R_{\mathrm{o}}$ (minimum $10^{6}-10^{7}$ yrs. under the above temperature). Thus, dating fluid flow may be a new way to reconstruct the tectonic history and may have extensive applications.

4) The late Paleocene (51 $\pm 3-59 \pm 4 \mathrm{Ma})$ large-scale fluid flow is recognized from all the AFT ages according to the thermal overprinting effect. The large-scale fluid flow calls for a new idea to direct the hydrocarbon exploration.

\section{Acknowledgements}

The authors are grateful to the Daqing Oilfield Company, CNPC, for supporting the field work and providing the original geologic data. The samples were prepared and analyzed under the instruction of Prof. Yuan Wanming from China University of Geosciences. Valuable suggestions from two anonymous reviewers are greatly appreciated. This work was supported by the National Natural Science Foundation of China (Grant Nos. 40872097 and 41272161) and the Major National Science \& Technology Program (Grant Nos. 2011ZX05006-005 and 2011ZX05006-006). The field trip is partly funded by the State Key Laboratory for Petroleum Resource and Prospecting (Grant No. KYJJ2012-01-12).

\section{References}

Bachu S. Influence of lithology and fluid flow on the temperature 
distribution in a sedimentary basin: A case study from the Cold Lake area, Alberta, Canada. Tectonophysics. 1985. 120: 257-284

Barker C E. Temperature and time in the thermal maturation of sedimentary organic matter. In: Naeser N D and McCulloh T H, Thermal History of Sedimentary Basins: Methods and Case Histories. Springer-Verlag, New York Inc. 1989. 73-98

Barker C E and Goldstein R H. Fluid-inclusion technique for determining maximum temperature in calcite and its comparison to the vitrinite reflectance geothermometer. Geology. 1990. 18(10): 1003-1006

Barker C E and Pawlewicz M J. An empirical determination of the minimum number of measurements needed to estimate the mean random vitrinite reflectance of disseminated organic matter. Organic Geochemistry. 1993. 20(6): 643-651

Barker S L L, Cox S F, Eggins S M, et al. Microchemical evidence for episodic growth of antitaxial veins during fracture-controlled fluid flow. Earth and Planetary Science Letters. 2006. 250(1-2): 331-344

Bernet $\mathrm{M}$ and Garver J I. Fission-track analysis of detrital zircon. Reviews in Mineralogy and Geochemistry. 2005. 58: 205-238

Blackwell D D and Steele J L. Thermal conductivity of sedimentary rocks: Measurement and significance. In: Naeser N D and McCulloh T H, Thermal History of Sedimentary Basins: Methods and Case Histories. Springer-Verlag, New York. 1989. 13-36

Burnham A K and Sweeney J J. A chemical kinetic model of vitrinite maturation and reflectance. Geochimica et Cosmochimica Acta. 1989. 53(10): 2649-2657

Cai Y C and Fu X F. Current geothermal field of medium-shallow layers in Binbei area and its thermal evolution history. Petroleum Geology and Oilfield Development in Daqing. 2005. 24(4): 8-10 (in Chinese)

Carlson W D, Donelick R A and Ketcham R A. Variability of apatite fission-track annealing kinetics: I. Experimental results. American Mineralogist. 1999. 84: 1224-1234

Carr A D. A vitrinite reflectance kinetic model incorporating overpressure retardation. Marine and Petroleum Geology. 1999. 16(4): 355-377

Cheng R H, Wang G D, Wang P J, et al. Description of Cretaceous sedimentary sequence of the Yaojia Formation recovered by CCSDSK-Is borehole in Songliao Basin: Lithostratigraphy, sedimentary facies and cyclic stratigraphy. Earth Science Frontiers. 2009. 16(2): 140-151

Crowley K D, Cameron M and Schaefer R I. Experimental studies of annealing of etched fission tracks in fluorapatite. Geochimica et Cosmochimica Acta. 1991. 55(5): 1449-1465

Danišík M, Migon P, Kuhlemann J, et al. Thermochronological constraints on the long-term erosional history of the Karkonosze Mts., Central Europe. Geomorphology. 2010. 117(1-2): 78-89

Donelick R A and Miller D S. Enhanced TINT fission track densities in low spontaneous track density apatites using ${ }^{252} \mathrm{Cf}$-derived fission fragment tracks: A model and experimental observations. Nuclear Tracks and Radiation Measurements. 1991. 18(3): 301-307

Donelick R A, O'Sullivan P B and Ketcham R A. Apatite fission-track analysis. Reviews in Mineralogy and Geochemistry. 2005. 58(1): 49-94

Ehlers T A. Crustal thermal processes and the interpretation of thermochronometer data. Reviews in Mineralogy and Geochemistry. 2005. 58(1): 315-350

Feng Z H, Liao G Z, Fang W, et al. Formation of heavy oil and correlation of oil-source in the western slope of the northern Songliao Basin. Petroleum Exploration and Development. 2003. 30(4): 25-28 (in Chinese)

Feng Z Q. Volcanic rocks as prolific gas reservoir: A case study from the Qingshen gas field in the Songliao Basin, NE China. Marine and Petroleum Geology. 2008. 25(4-5): 416-432

Feng Z Q, Jia C Z, Xie X N, et al. Tectonostratigraphic units and stratigraphic sequences of the nonmarine Songliao Basin, northeast
China. Basin Research. 2010a. 22(1): 79-95

Feng Z Q, Zhang S, Cross T A, et al. Lacustrine turbidite channels and fans in the Mesozoic Songliao Basin, China. Basin Research. 2010b. 22(1): 96-107

Galbraith R F. The radial plot: graphical assessment of spread in ages. Nuclear Tracks and Radiation Measurements. 1990. 17(3): 207-214

Galbraith R F and Laslett G M. Statistical models for mixed fission track ages. Nuclear Tracks and Radiation Measurements. 1993. 21(4): 459470

Garven G, Ge S, Person M A, et al. Genesis of stratabound ore deposits in the midcontinent basins of north America. 1. The role of regional groundwater flow. American Journal of Science. 1993. 293: 497-568

Gleadow A J W. Fission-track dating methods: What are the real alternatives? Nuclear Tracks. 1981. 5(1-2): 3-14

Gleadow A J W, Duddy I R, Green P F, et al. Fission track lengths in the apatite annealing zone and the interpretation of mixed ages. Earth and Planetary Science Letters. 1986. 78(2-3): 245-254

Gordon R G and Jurdy D M. Cenozoic global plate motions. Journal of Geophysical Research. 1986. 91(B12): 12389-12406

Green P F, Duddy I R, Gleadow A J W, et al. Fission-track annealing in apatite: Track length measurements and the form of the Arrhenius plot. Nuclear Tracks. 1985. 10(3): 323-328

Green P F, Duddy I R, Laslett G M, et al. Thermal annealing of fission tracks in apatite 4: Quantitative modeling techniques and extension to geological timescales. Chemical Geology: Isotope Geoscience Section. 1989. 79(2): 155-182

Hansen K, Bergman S C and Henk B. The Jameson Land Basin (east Greenland): A fission track study of the tectonic and thermal evolution in the Cenozoic North Atlantic spreading regime. Tectonophysics. 2001. 331(3): 307-339

Hou Q J, Meng Q A and Zhang G. Characters of fluid inclusions in the Fuyang reservoir, Qijia-Gulong area, Songliao Basin. Petroleum Exploration and Development. 2004. 31(4): 48-51 (in Chinese)

Hurford A J. Standardization of fission track dating calibration: Recommendation by the fission track working group of the IUGS subcommision on geochronology. Chemical Geology: Isotope Geoscience Section. 1990. 80(2): 171-178

Hurford A J and Green P F. The zeta age calibration of fission track dating. Chemical Geology. 1983. 41: 285-317

Hutton A C and Cook A C. Influence of alginite on the reflectance of vitrinite from Joadja, NSW, and some other coals and oil shales containing alginite. Fuel. 1980. 59(10): 711-714

ICCP. The new vitrinite classification (ICCP System). Fuel. 1998. 77: 349-358

ISO. 7404-5 (E). Methods for the petrographic analysis of bituminous coal and anthracite: Part 5. Method of determining microscopically the reflectance of vitrinite. International Standard. 2nd Edition. 1994. $1-13$

Ketcham R A, Donelick R A and Carlson W D. Variability of apatite fission-track annealing kinetics III: Extrapolation to geological time scales. American Mineralogist. 1999. 84: 1235-1255

Laslett G M, Green P F, Duddy I R, et al. Thermal annealing of fission tracks in apatite 2: A quantitative analysis. Chemical Geology: Isotope Geoscience Section. 1987. 65(1): 1-13

Lee T Y and Lawver L A. Cenozoic plate reconstruction of Southeast Asia. Tectonophysics. 1995. 251(1-4): 85-138

Lin T F, Xiang C F, Feng Z H, et al. Pathway systems for hydrocarbon migration to Binbei district, Songliao Basin, Northeast China. Geological Science and Technology Information. 2009. 28(1): 63-68 (in Chinese)

Liu W L, Li S T, Sun D J, et al. Prediction of pore fluid pressure in deep strata of Songliao Basin. Earth Science-Journal of China University of Geosciences. 2000. 25(2): 137-142 (in Chinese)

Lo H B. Correction criteria for the suppression of vitrinite reflectance 
in hydrogen-rich kerogens: Preliminary guidelines. Organic Geochemistry. 1993. 20(6): 653-657

$\mathrm{Lu} \mathrm{B}$, Li B, Liu Z, et al. Basement fracture features and their controlling over the hydrocarbon at Binbei area in Songliao Basin. Journal of Daqing Petroleum Institute. 2000. 24(4): 8-11 (in Chinese)

Lu S F, Li J N, Liu S J, et al. Oil generation threshold depth of Songliao Basin: Revision and its significance. Petroleum Exploration and Development. 2009. 36(2): 166-173 (in Chinese)

Lutz T M and Omar G. An inverse method of modeling thermal histories from apatite fission track data. Earth and Planetary Science Letters. 1991. 104(2-4): 181-195

Ma C Y, Wang H X and Fu C C. Analysis of the temperature time series variation and trend in Northeast China during the last 50 years. Journal of Changchun Normal University (Natural Science). 2009. 28(6): 55-59 (in Chinese)

Maruyama S and Send T. Orogeny and relative plate motions: Example of the Japanese islands. Tectonophysics. 1986. 127(3-4): 305-329

Maruyama S, Liou J G and Seno T. Mesozoic and Cenozoic evolution of Asia. In: Ben-Avraham Z, The Evolution of the Pacific Ocean Margins. New York: Oxford University. 1989. 75-99

Miller D S and Duddy I R. Early Cretaceous uplift and erosion of the northern Appalachian basin, New York, based on apatite fission track analysis. Earth and Planetary Science Letters. 1989. 93(1): 35-49

Oliver N H S and Bons P D. Mechanism of fluid flow and fluid-rock interaction in fossil metamorphic hydrothermal systems inferred from vein-wall rock patterns, geometry and microstructure. Geofluids. 2001. 1: 137-162

Patriat $\mathrm{P}$ and Achache J. Indo-Eurasian collision chronology has implications for crustal shorting and driving mechanism of plates. Nature. 1984. 311: 615-621

Ren Z L, Xiao D M and Chi Y L. Restoration of the palaeogeotherm in Songliao Basin. Petroleum Geology and Oilfield Development in Daqing. 2001. 20(1): 13-14 (in Chinese)

Resak M, Glasmacher U A, Narkiewicz M, et al. Maturity modelling integrated with apatite fission-track dating: Implications for the thermal history of the Mid-Polish Trough (Poland). Marine and Petroleum Geology. 2010. 27(1): 108-115

Sharp W D and Clague D A. 50-Ma initiation of Hawaiian-Emperor bend records major change in Pacific plate motion. Science. 2006. 313(5791): 1281-1284

Sibson R H. Tectonic controls on maximum sustainable overpressure: Fluid redistribution from stress transitions. Journal of Geochemical Exploration. 2000. 69-70: 471-475

Sibson R H. Brittle-failure controls on maximum sustainable overpressure in different tectonic regimes. AAPG Bulletin. 2003. 87(6): 901-908

Song T G. Inversion styles in the Songliao Basin (northeast China) and estimation of the degree of inversion. Tectonophysics. 1997. 283(14): $173-188$

Spiegel C, Kohn B, Raza A, et al. The effect of long-term lowtemperature exposure on apatite fission track stability: A natural annealing experiment in the deep ocean. Geochimica et Cosmochimica Acta. 2007. 71(18): 4512-4537

Stanislavsky E and Garven G. A theoretical model for reverse waterlevel fluctuations induced by transient permeability in thrust fault zones. Earth and Planetary Science Letters. 2003. 210(3-4): 579-586

Sun F H, Yuan J and Guan Y. Asymmetric change of maximum and minimum temperature in the Northeast China from 1959-2002. Scientia Geographica Sinica. 2009. 28(4): 532-536 (in Chinese)

Su Y P, Fu X F, Lu S F, et al. Application of Easy $\% R_{0}$ model to the research of thermal evolution in Binbei. Journal of Daqing Petroleum Institute. 2006. 30(2): 5-12 (in Chinese)

Tagami T and O'Sullivan P B. Zircon fission-track thermochronology and applications to fault studies. Reviews in Mineralogy and Geochemistry. 2005. 58(1): 99-122

Wagner G A. Fission-track ages and their geological interpretation. Nuclear Tracks. 1981. 5(1-2): 15-25

Wagner G A, Gleadow A J W and Fitzgerald P G. The significance of the partial annealing zone in apatite fission-track analysis: Projected track length measurements and uplift chronology of the Transantarctic Mountains. Chemical Geology. 1989. 79(4): 295-305

Wang F, Zhou X H, Zhang L C, et al. Late Mesozoic volcanism in the Great Xing' an range (NE China): Timing and implications for the dynamic setting of NE Asia. Earth and Planetary Science Letters. 2006a. 251(1-2): 179-198

Wang H Y, Kang X D, Li J, et al. The distribution of anomalous pressure in the deep zone of Xujiaweizi, Songliao Basin and its genesis. Journal of Jilin University (Earth Science Edition). 2002. 32(1): 3942 (in Chinese)

Wang P J, Cheng R H, Wang H Y, et al. Strategy for next step oil \& gas exploration in northern Songliao Basin. Petroleum Exploration and Development. 2006b. 33(4): 426-431 (in Chinese)

Wang P J, Gao Y F, Cheng R H, et al. Description of Cretaceous sedimentary sequence of the second and third members of the Qingshankou Formation recovered by CCSD-SK-Is borehole in Songliao Basin: Lithostratigraphy, sedimentary facies and cyclic stratigraphy. Earth Science Frontiers. 2009. 16(2): 288-313

Wu H C, Zhang S H and Huang Q H. Establishment of floating astronomical time scale for the terrestrial late Cretaceous Qingshankou Formation in the Songliao Basin of northeast China. Earth Science Frontiers. 2008. 15(4): 159-169

Xiang C F, Feng Z Q, Pang X Q, et al. Late stage thermal history of the Songliao Basin and its tectonic implications: Evidence from apatite fission track (AFT) analysis. Science in China Series D: Earth Sciences. 2007. 50(10): 1479-1487 (in Chinese)

Xiang C F, Feng Z Q, Wu H Y, et al. Discussion on the dynamic factors controlling hydrocarbon migration from depression to west slope zone of the Songliao Basin, Northeast China. Acta Sedimentologica Sinica. 2005. 23: 719-725 (in Chinese)

Xiang C F, Wang F D, Peng P, et al. Late-stage tectonic inversion and its significance: Evidence from the uplifting and denudation history of the Songliao Basin. AAPG 2010 Annual Convention and Exhibition Abstract. New Orleans. 2010

Xiang C F, Xia B, Xie X N, et al. Tracing hydrocarbon migration by integrated analysis of different kinds of tracers in western slope zone of Songliao Basin, Northeast China. Geological Science and Technology Information. 2004. 23(4): 64-70 (in Chinese)

Yang W L. Daqing oil field, People's Republic of China: A giant field with oil of nonmarine origin. AAPG Bulletin. 1985. 69: 1101-1111

Yang W L, Li Y K and Gao R Q. Formation and evolution of non-marine petroleum in Songliao Basin, China. AAPG Bulletin. 1985. 69: $1112-1122$

Yu P, Li R L, Fu L, et al. Regional tectonic characteristics and significance of north Harbin area in Songliao Basin: Evidence from long seismic profiles. Journal of Jilin University (Earth Science Edition). 2005. 35(5): 611-615 (in Chinese)

Zhao W Z, Wang H J, Yuan X J, et al. Petroleum systems of Chinese nonmarine basins. Basin Research. 2010. 22(1): 4-16

Zhao W Z, Zou C N, Feng Z Q, et al. Geological features and evaluation techniques of deep seated volcanics gas reservoirs, Songliao Basin. Petroleum Exploration and Development. 2008. 35(2): 129-142 (in Chinese)

Zhou Y S and Littke R. Numerical simulation of the thermal maturation, oil generation and migration in the Songliao Basin, Northeastern China. Marine and Petroleum Geology. 1999. 16(8): 771-792

(Edited by Hao Jie) 